\section{Acknowledgment}

The author is grateful to Prof. M. Matsubara of Daido Inst. of Tech. for his guidance and to Mr. Shunichi Nagasato and Mr. Tomoo Yamashita for their assistance during the calculation work.

\begin{tabular}{|c|c|c|}
\hline \multicolumn{2}{|c|}{ Nomenclature } & \\
\hline$C_{P}$ & $=$ & molar heat capacity \\
\hline$d v$ & $=$ & deviation \\
\hline$G$ & $=$ & gas molar velocity \\
\hline$h_{G^{a}} a$ & $=$ & $\begin{array}{l}\text { volumetric heat transfer coefficient } \\
\text { (gas phase) }\end{array}$ \\
\hline$h_{L} a$ & $=$ & $\begin{array}{l}\text { volumetric heat transfer coefficient } \\
\text { (liquid phase) }\end{array}$ \\
\hline$K$ & $=$ & equilibrium ratio \\
\hline$k_{W} a$ & & $\begin{array}{l}\text { volumetric mass transfer coefficient } \\
\text { (solvent vapor in gas phase) }\end{array}$ \\
\hline$k_{x} a$ & $=$ & $\begin{array}{l}\text { volumetric mass transfer coefficient } \\
\text { (solute in liquid phase) }\end{array}$ \\
\hline$k_{y} a$ & & $\begin{array}{l}\text { volumetric mass transfer coefficient } \\
\text { (solute in gas phase) }\end{array}$ \\
\hline$L$ & $=$ & liquid molar velocity \\
\hline$N$ & $=$ & total number of cells \\
\hline$N$ & $=$ & mass transfer rate \\
\hline$P$ & $=$ & total pressure \\
\hline$p$ & $=$ & partial pressure \\
\hline$q$ & & heat transfer rate \\
\hline$t$ & $=$ & temperature \\
\hline$x$ & & concentration of solute in liquid \\
\hline$y$ & & concentration of solute in gas \\
\hline
\end{tabular}

$\left[\mathrm{mol} / \mathrm{m}^{3} \cdot \mathrm{s}\right]$

$\left[\mathrm{mol} / \mathrm{m}^{2} \cdot \mathrm{s}\right]$

$\left[\mathrm{mol} / \mathrm{m}^{2} \cdot \mathrm{s}\right]$

[Pa]

$[\mathrm{Pa}]$

$\left[\mathrm{W} / \mathrm{m}^{2}\right]$

[mol/mol]

[mol/mol] $\begin{array}{llr}w & =\text { concentration of solvent in gas } & {[\mathrm{mol} / \mathrm{mol}]} \\ Z & =\text { tower height } & {[\mathrm{m}]} \\ \lambda_{A} & =\text { heat of solution } & {[\mathrm{J} / \mathrm{mol}]} \\ \lambda_{W} & =\text { latent heat of vaporization } & {[\mathrm{J} / \mathrm{mol}]} \\ \Delta Z & =\text { height of cell } & {[\mathrm{m}]}\end{array}$

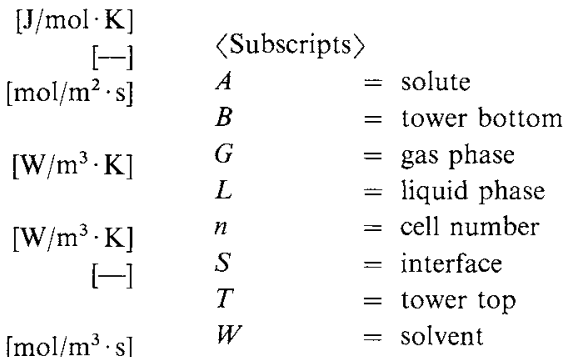

$\left[\mathrm{mol} / \mathrm{m}^{3} \cdot \mathrm{s}\right] \quad$ Literature Cited

1) Inazumi, H., T. Suzuki and S. Yamaguchi: Kagaku Kōgaku, 36, 768 (1972).

2) Kagaku Kogaku Kyokai: "Kagaku Kogaku Benran, 4th Ed.," p. 509, Maruzen, Tokyo (1978).

3) Kunugita, E.: Kagaku Kōgaku, 27, 900 (1963).

4) Raal, J. D. and M. K. Khuroma: Can. J. Chem. Eng., 51, 162 (1973).

5) Stocker, U. V. and Wilke, R.: Ind. Eng. Chem., Fundam., 16, $88(1977)$.

6) Treybal, R. E.: Ind. Eng. Chem., 61, 36 (1969).

7) Yoshifuku, I.: J. Chem. Eng. Japan, 18, 137 (1985).

\title{
FUZZY CONTROL OF BLOOD PRESSURE BY DRUG INFUSION
}

YOSHIYUKI YAMASHITA AND MUTSUMI SUZUKI

Department of Chemical Engineering, Tohoku University, Sendai 980

KOICHI KAMBE

Department of Urology, School of Medicine, Tohoku University, Sendai 980

Key Words: Process Control, Fuzzy Control, Blood Pressure, Biomedical Engineering, Hypertensive

Chemotherapy

\section{Introduction}

It is necessary to control the arterial blood pressure in many clinical situations. Hypertensive crisis, postoperative recovery and induced-hypertensive chemotherapy are examples of such cases. In an actual clinical situation, blood pressure is often difficult to control even by experienced doctors. Several approaches toward automated blood pressure controllers have been reported. ${ }^{1,2.3)}$ It is pointed out that the

Received December 28, 1987. Correspondence concerning this article should be addressed to Y. Yamashita. action of some controllers does not always match the judgment of doctors.

In this work, the control operation of a skilled doctor was emulated as a preliminary approach. Fuzzy control was applied to the automatic control of blood pressure by hypertensive drug infusion. The main characteristic of this method is that the controller action is very close to human judgment. The fuzzy controller used in this work was originally developed for the control of packed bed reactors. ${ }^{4)}$ Almost the same algorithm could be used for the present case with a little modification. 
Table 1. Quantized membership functions for fuzzy linguistic values

\begin{tabular}{|c|c|c|c|c|c|c|c|c|c|c|c|c|c|}
\hline \multirow{2}{*}{ Value } & \multicolumn{13}{|c|}{ Element } \\
\hline & -6 & -5 & -4 & -3 & -2 & -1 & 0 & 1 & 2 & 3 & 4 & 5 & 6 \\
\hline $\mathrm{PB}$ & 0 & 0 & 0 & 0 & 0 & 0 & 0 & 0 & 0 & 0.1 & 0.4 & 0.8 & 1.0 \\
\hline PM & 0 & 0 & 0 & 0 & 0 & 0 & 0 & 0 & 0.2 & 0.8 & 1.0 & 0.7 & 0.2 \\
\hline PS & 0 & 0 & 0 & 0 & 0 & 0 & 0.2 & 0.8 & 1.0 & 0.7 & 0.2 & 0 & 0 \\
\hline NS & 0 & 0 & 0.2 & 0.7 & 1.0 & 0.8 & 0.2 & 0 & 0 & 0 & 0 & 0 & 0 \\
\hline NM & 0.2 & 0.7 & 1.0 & 0.8 & 0.2 & 0 & 0 & 0 & 0 & 0 & 0 & 0 & 0 \\
\hline NB & 1.0 & 0.8 & 0.4 & 0.1 & 0 & 0 & 0 & 0 & 0 & 0 & 0 & 0 & 0 \\
\hline
\end{tabular}

\section{Experimental Apparatus and Procedure}

\subsection{Experimental apparatus}

Animal experiments were carried out on rats. A schematic diagram of the experimental apparatus is shown in Fig. 1. Mean arterial pressure was measured by using a transducer through a catheter placed in the external iliac artery. The mean pressure signal was obtained by passing the measured signal through a low-path filter to remove high-frequency components. A 12-bit A/D converter was used for digitalization of the mean pressure. Angiotensin-II (AT-II) was used as the hypertensive drug. Just before the experiments, AT-II $(0.1 \mathrm{mg} /$ ampoule $)$ was dissolved in $100 \mathrm{ml}$ of physiological saline solution. AT-II was infused from the external iliac vein by using a digitally controlled infusion pump. The control algorithm was implemented with a personal computer with a 16-bit CPU.

\subsection{Control algorithm}

The controller used in this work is almost the same as that in the previous work, ${ }^{4}$ so only a short description is given here.

When a person controls the pressure, he seems to pay attention to the difference between target and observed value. This control policy can be represented by the following linguistic rules.

"If the pressure is lower than the target, increase the infusion rate. If the pressure is near the target but is still increasing, decrease the infusion rate."

These rules can be treated mathematically by using the fuzzy controller based on the linguistic rules shown as follows:

$$
\begin{aligned}
\text { IF } e=\mathrm{E}_{1} \text { AND } c=\mathrm{C}_{1} \text { THEN } u=\mathrm{U}_{1} \\
\text { ELSE IF } e=\mathrm{E}_{2} \text { AND } c=\mathrm{C}_{2} \text { THEN } u=\mathrm{U}_{2}
\end{aligned}
$$

Here, the variable $e$ means difference between current mean arterial pressure and set point. The change of $e$ in a sampling period is denoted as $c$, and $u$ indicates a change of drug infusion rate. Let the drug infusion rate be $r$, and the variables are described as follows at time step $k$ :

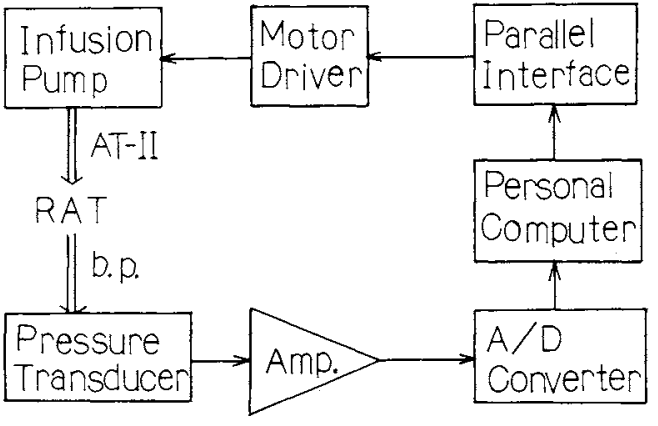

Fig. 1. Experimental apparatus of blood pressure control system

Table 2. Ranges of fuzzy variables

\begin{tabular}{ccl}
\hline Variables & Range & Unit \\
\hline$e$ & $-20-20$ & $\mathrm{mmHg}$ \\
$c$ & $-30-30$ & $\mathrm{mmHg}$ \\
$u$ & $-1.0-1.0$ & $\mathrm{ml} / \mathrm{h}$ \\
\hline
\end{tabular}

$$
\begin{aligned}
& e(k)=y_{t}-y(k) \\
& c(k)=e(k)-e(k-1) \\
& r(k)=r(k-1)+u(k)
\end{aligned}
$$

All these scalar variables are considered as fuzzy singletons; thus fuzzy rule Eq. (1) can be evaluated. Large characters $\mathrm{E}_{i}, \mathrm{C}_{i}$ and $\mathrm{U}_{i}$ are linguistic values such as NB and ZO. They are represented by fuzzy sets defined as in Table 1 as a quantized reference table. From the response of blood pressure to drug infusion rate, ranges of each variable are determined as shown in Table 2. In the present work, scaling factors for all variables are fixed. Detailed control rules used in the experiments are summarized as a state-action diagram in Table 3.

\section{Results and Discussion}

The algorithm above was applied experimentally to AT-II induced hypertension in rats. An example of control results with sampling time of 20 seconds is shown in Fig. 2. At first, the infusion rate of AT-II is set to zero and the mean arterial pressure is around 
Table 3. State-action diagram of control rules

\begin{tabular}{|c|c|c|c|c|c|c|c|}
\hline \multirow{2}{*}{$c$} & \multicolumn{7}{|c|}{$e$} \\
\hline & NB & NM & NS & $\mathrm{ZO}$ & PS & $\mathrm{PM}$ & PB \\
\hline $\mathrm{PB}$ & & & $\mathrm{NM}$ & $\mathrm{NB}$ & NB & & \\
\hline PM & & & NS & NM & NM & & \\
\hline PS & $\mathrm{PM}$ & PM & $\mathrm{ZO}$ & NS & NS & NM & NB \\
\hline $\mathrm{ZO}$ & $\mathrm{PB}$ & PM & PS & $\mathrm{ZO}$ & NS & $\mathrm{NM}$ & NB \\
\hline $\mathrm{NS}$ & $\mathrm{PB}$ & PM & PS & PS & $\mathrm{ZO}$ & NM & NB \\
\hline NM & & & PM & PM & PS & & \\
\hline NB & & & PM & PB & PM & & \\
\hline
\end{tabular}
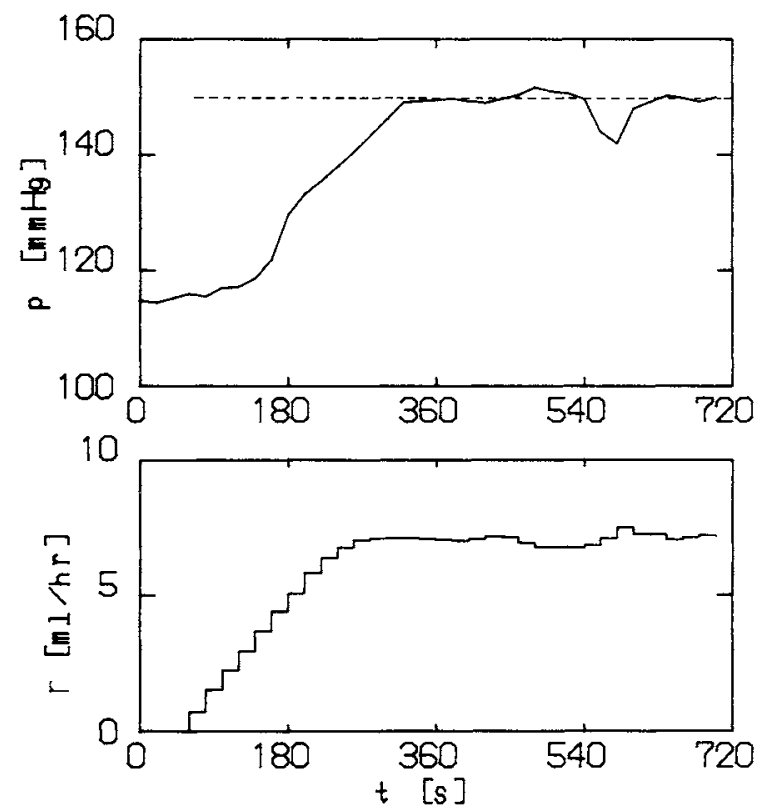

Fig. 2. Blood pressure response for a fuzzy controlled system

$115 \mathrm{mmHg}$. After 60 seconds, the controller start to set the pressure at around $150 \mathrm{mmHg}$. Then the infusion rate of AT-II increased gradually and the pressure rose. In about 300 seconds the target value was established without overshooting. The mean pressure was sufficiently maintained at the target point until a large disturbance was added.

To check the regulation characteristics, an anesthetic, ethyl ether, was added as a disturbance at 530 seconds As the effect of the anesthetic, the pressure decreased quickly. However, it recovered to the target level in about 60 seconds. This result shows that the controller has sufficient stability to offset a disturbance.

Despite differences in individuals and conditions, experiments on other rats were successfuly.

\section{Conclusions}

Blood pressure was successfully controlled with our fuzzy control system. The system works by adjusting the infusion rate of hypertensive drug AT-II. Experiments on rats showed acceptable performance both in regulation and in tracking. In particular, the system's stability in trials with numbers of rats was satisfactory, and the control. action fits human judgment. This system can be applied clinically in support of induced-hypertension chemotherapy.

\section{Acknowledgment}

The authors express their gratitude to Miss Motoko Okuhara and Miss Yuki Murakami for their cooperation in the experiments. Gratitude is also expressed to Yachiyoda Kogyo Co. Ltd. for constructing the apparatus.

Nomenclature

\begin{tabular}{|c|c|}
\hline$c$ & $=$ change of $e$ in a sampling period \\
\hline$e$ & $=$ difference between $y_{t}$ and $y$ \\
\hline$k$ & $=$ time step \\
\hline$r$ & $=$ infusion rate of drug \\
\hline$u$ & $=$ change of $r$ in a sampling period \\
\hline$y$ & $=$ mean arterial pressure \\
\hline$y_{t}$ & $=$ target value of $y$ \\
\hline
\end{tabular}

\section{Literature Cited}

1) He, W. G., H. Kaufman and R. Roy: IEEE Trans. Biomedical Eng., BME-33, 10 (1986).

2) Kaufman, H., R. Roy and X. Xu: Automatica, 20, 205 (1984)

3) Walker, B. K., T. L. Chia, K. S. Stern and P. G. Katona: IFAC Identification and System Parameter Estimation, 1413 (1982).

4) Yamashita, Y., S. Matsumoto and M. Suzuki: J. Chem. Eng. Japan, 21, 277 (1988).

(A part of this paper was presented at the Hokkaido Meeting of The Soc. of Chem. Engrs., Japan at Sapporo, D-102, July 1987.) 